JAMP: Jurnal Adminitrasi dan Manajemen Pendidikan

Volume 3 Nomor 1 Maret 2020, Hal : 52-60

Tersedia Online di http://journal2.um.ac.id/index.php/jamp/

ISSN 2615-8574 (online)

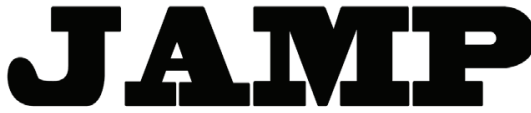

JURNAL ADMINISTRASI DAN MANAJEMEN PENDIDIKAN

\title{
MANAJEMEN KEGIATAN EKSTRAKURIKULER BROADCASTING DALAM MENINGKATKAN KREATIVITAS PESERTA DIDIK
}

\author{
Ahmat Hanafi \\ Nurul Ulfatin \\ Wildan Zulkarnain \\ Universitas Negeri Malang, Jl. Semarang 05 Malang 65145 \\ Ahmathanafi80@gmail.com
}

\begin{abstract}
The purpose of this study is to describe in detail the activities of broadcasting extracurricular activities in increasing the creativity of students at SMKN 4 Malang, which starts from the planning, organizing, implementing, evaluating and creative stages obtained by students. This research was conducted a qualitative approach to the type of case study research to obtain descriptive nature, comprehensive, and incentives. The results of this study explain about the planning, organizing, implementing, evaluating, and creativity activities that are gained by students in participating in extracurricular broadcasting activities at SMKN 4 Malang.
\end{abstract}

Key Words: management of extracurricular activities, broadcasting, creativity

\begin{abstract}
Abstrak: Tujuan dari penelitian ini yaitu mendeskripsikan secara rinci mengenai kegiatan ekstrakurikuler broadcasting dalam meningkatkan kreativitas peserta didik di SMKN 4 Kota Malang, yang dimulai dari tahap perencanaan, pengorganisasian, pelaksanaan, evaluasi dan juga kreatif yang didapat oleh peserta didik. Penelitian ini dilakukan pendekatan kualitatif jenis penelitian studi kasus untuk memperoleh deskriptif secara alamiah, komprehensif, dan insentif. Hasil pada penelitian ini menjelaskan mengenai kegiatan perencanaan, pengorganisasian, pelaksanaan, evaluasi, dan kreativitas apa yang didapat oleh peserta didik dalam mengikuti kegiatan ekstrakurikuler broadcasting di SMKN 4 Kota Malang.
\end{abstract}

Kata Kunci: manajemen kegiatan ekstrakurikuler, broadcasting, kreativitas

Sekolah dapat dijadikan sebagai wadah yang dapat mendukung tercapainya tujuan pendidikan. Ketercapaian tujuan pendidikan tidak lepas dari pengaruh kurikulum pendidikan yaitu pada kegiatan ekstrakurikuler. Maka dari itu pelaksanaan dan pengembangan kurikulum dapat dilakukan dengan melaksanakan dan mengembangkan kegiatan ekstrakurikuler. Hal tersebut juga disebutkan di Undangundang Sistem Pendidikan Nasional No.20 Tahun 2003 Pasal 3 menyatakan bahwa pendidikan nasional berfungsi mengembangkan dan membentuk watak serta peradaban bangsa yang bermartabat dalam rangka mencerdaskan kehidupan bangsa, bertujuan untuk berkembangnya potensi peserta didik agar menjadi manusia yang beriman dan ertakwa kepada Tuhan Yang Maha Esa, berakhlak mulia, serta berilmu, cakap, kreatif, mandiri, dan menjadi warga negara yang demokratis serta bertanggung jawab.

Dalam pelaksanaan kegiatan ekstrakurikuler biasanya dilaksanakan di luar jam pelajaran tetap guna memperluas wawasan dan nilai pengetahuan dan kemampuan pada berbagai bidang yaitu, olahraga, keagamaan, maupun kesenian. Adanya ekstrakurikuler di sekolah merupakan salah satu cara untuk menampung dan mengembangkan potensi peserta didik saat di sekolah. Pelaksanaan kegiatan 
ekstrakurikuler di sekolah merupakan bagian dari pendidikan sesuai dengan Peraturan Pendidikan dan Kebudayaan Republik Indonesia Nomor 62 Tahun 2014 tentang Kegiatan Ekstrakurikuler Pada Pendidikan Dasar dan Pendidikan Menengah. Pada peraturan tersebut menyatakan bahwa kegiatan ekstrakurikuler ialah kegiatan yang dilaksanakan di luar jam kegiatan kurikuler. Kegiatan kurikuler dalam proses belajar mengajar di kelas dapat berbentuk mata pelajaran maupun bidang studi di sekolah. Sedangkan ekstrakurikuler merupakan wadah kegiatan peserta didik di luar kegiatan kurikuler. Kegiatan ekstrakurikuler ini dilakukan setiap lembaga sekolah dari jenjang Taman Kanak-Kanak (TK) hingga Sekolah Menengah Atas (SMA) maupun Sekolah Menengah Kejuruan (SMK) dengan bermacammacam kegiatan ekstrakurikuler.

SMKN 4 Malang merupakan sekolah yang berusaha meningkatkan mutu peserta didiknya. SMKN 4 Malang sendiri berusaha mewadahi segala kebutuhan peserta didiknya untuk mengasah keterampilan dan kemampuan diri setiap peserta didik. Dengan demikian, SMKN 4 Malang sebagai wadah untuk mengembangkan potensi peserta didiknya dengan meningkatkan mutu pendidikan dari segi akademik maupun non akademik. Di lihat dari akademiknya, sekolah selalu meningkatkan kualitas pendidikan dan meningkatkan proses pembelajaran. Dari segi non akademik ialah meningkatkan proses kegiatan ekstrakurikuler. Pada kegiatan ekstrakurikuler yang dikembangkan di SMKN 4 Malang salah satunya yaitu ekstrakurikuler broadcasting. Menurut Indarti (2017) broadcast adalah salah satu cabang dari ilmu komunikasi yang berhubungan dengan penyiaran. Di dalam broadcasting sendiri merupakan membuat konten sebuah siaran mulai dari praproduksi-produksi-pascaproduksi.

Pada era milenial saat ini sumber banyak masyarakat yang ingin mempunyai berita sangat cepat dan ter-update dengan hal itu ekstrakurikuler broadcasting membuat konten video tentang edukasi terhadap masyarakat isu saat ini. Pada ekstrakurikuler broadcasting ini untuk mewadahi karya-karya yang telah dibuat juga memanfaatkan media sosial instragram dan youtube untuk mempublikasi hasil karya maupun dokumentasi event-event yang ada di sekolah SMKN 4 Malang agar masyarakat bisa mengetahui infoinfo yang ada di sekolah maupun isu di masyarakat saat ini dan ekstrakurikuler broadcasting ini menjadi penengah dengan isu yang ada pada saat ini. Ekstrakurikuler broadcasting juga mengikuti event lomba yang diadakan oleh perusahaan swasta. Lomba yang diikuti oleh ekstrakurikuler broadcasting ini tentang bentuk film pendek atau video pendek.

Kegiatan ekstrakurikuler broadcasting ini meningkat kreativitas peserta didik melalui IT. Untuk kegiatan ekstrakurikuler broadcasting sangatlah mudah untuk di ikuti karena tinggal mengisi form melalui online jadi mempermudah peserta didik untuk bisa mengikuti kegiatan ekstrakurikuler broadcasting di SMKN 4 Kota Malang. Ekstrakurikuler broadcasting ini sebagai wadah untuk belajar untuk peserta didik jadi tidak ada seleksi untuk masuk atau belajar tentang broadcasting. kreativitas yang dihasilkan peserta didik yaitu tentang pembuatan konten film pendek dan video edukasi kepada masyarakat, tidak hanya itu juga ekstrakurikuler broadcasting juga mewadahi untuk peserta didik yang mempunyai talent untuk dijadikan sebagai obyek model untuk pembelajaran fotografi dan berperan dalam pembuatan video maupun film pendek. Untuk mengikuti kegiatan ekstrakurikuler broadcasting juga semua jurusan yang ada di SMKN 4 Kota Malang bisa mengikuti. Sehingga peneliti mengambil judul Manajemen Kegiatan Ekstrakurikuler Brodcasting Dalam Meningkatkan Kreativitas Peserta Didik di Sekolah Menengah Kejuruan Negeri (SMKN) 4 Kota Malang.

Berdasarkan latar belakang penenlitian di SMKN 4 Kota Malang dengan fokus pada penelitian manajemen kegiatan ekstrakurikuler broadcasting dalam meningkatkan kreativitas peserta didik yakni (1) Perencanaan kegiatan ekstrakurikuler broadcasting yang meningkatkan kreativitas peserta didik di SMKN 4 Kota Malang, (2) Pengorganisasian kegiatan ekstrakurikuler broadcasting yang meningkatkan kreativitas peserta didik di SMKN 4 Malang, (3) Pelaksanaan kegiatan ekstrakurikuler broadcasting yang meningkatkan kreativitas peserta didik di SMKN 4 Malang, (4) Evaluasi kegiatan ekstrakurikuler broadcasting yang meningkatkan kreativitas peserta didik di SMKN 4 Malang, (5) Kreativitas yang didapat oleh peserta didik. Dan juga memiliki fokus tujuan sebagai berikut, (1) Mendeskripsikan kegiatan ekstrakurikuler broadcasting yang meningkatkan kretivitas peserta didik di SMKN 4 Kota Malang, (2) Mendeskripsikan pengorganisasian kegiatan ekstrakurikuler broadcasting yang meningkatkan kretivitas peserta didik di SMKN 4 Malang, (3) Mendeskripsikan pelaksanaan kegiatan ekstrakurikuler 
broadcasting yang meningkatkan kretivitas peserta didik di SMKN 4 Malang, (4) Mendeskripsikan evaluasi kegiatan ekstrakurikuler broadcasting yang meningkatkan kretivitas peserta didik di SMKN 4 Malang, (5) Mendeskripsikan kreativitas yang di dapat oleh peserta didik.

\section{METODE}

Penelitian yang digunakan yaitu penelitian pendekatan kualitatif dengan tujuan yaitu mendeskripsikan dan menggambarkan mengenai manajemen kegiatan ekstrakurikuler broadcasting. Pendekatan dilakukan karena memfokuskan pada penelitian yang berkaitan dengan proses sehingga diperlukan observasi dan pengamatan. Hal ini sesuai pendapat Ulfatin (2015) yang menyatakan bahwa dalam penelitian kualitatif, secara umum peneliti mendeskripsikan dan menggambarkan situasi sosial serta memaparkan situasi peristiwa yang terjadi di lapangan. Penelitian yang dilakukan yakni studi kasus, yang memfokuskan sasaran pada pengelolaan dari kegiatan ekstrakurikuler broadcasting di SMKN 4 Kota Malang. Menurut Ulfatin (2015) menggambarkan sasaran dari studi kasus bisa berupa peristiwa, manusia, latar dan dokumen yang telaah agar dapat memahami suatu hubungan dan proses yang berkaitan dengan unsur-unsur manajemen ekstrakurikuler. Peneltian ini digunakan peneliti dilakukan di Sekolah Menengah Kejuruan Negeri (SMKN) 4 Malang ini karena sekolah ini mengembangkan pemikiran kretivitas melalui kegiatan ekstrakurikuler broadcasting dengan fokus di penulisan, fotografi, videografi, dan juga reporter. Sumber dari data penelitian ini yaitu informan melalui sumber primer dan sekunder. Dengan sumber primer dan sekunder beberapa informan yang dijadikan sumber penelitian, sumber penelitian yang utama adalah Wakil Kepala Sekolah bidang Kesiswaan, Wakil Kepala Sekolah bagian SDM, pembina ekstrakurikuler broadcasting, Ketua Ekstrakurikuler Broadcasting, Sekertaris Ekstrakurikuler Broadcasting, Anggota Ekstrakurikuler Broadcasting. Oleh sebab itu sumber data yang diambil oleh peneliti didapat dari wawancara dan observasi yang mendalam.

Pengumpulan data yang dilakukan adalah dengan cara observasi, wawancara, dan dokumentasi. Teknik observasi yaitu dilakukan dengan menunjukkan surat observasi yang kemudian disepakati dan menentukan waktu. Setelah kesepakatan terjadi maka peneliti memiliki kesempatan untuk mengamati secara langsung dengan informan yaitu wakil kepala sekolah, pembina ekstrakurikuler, dan pengurus ekstrakurikuler. Untuk Analisis data dilakukansetelah pengumpulan data yang ada dilapangan yaitu reduksi data dan penyajian data. Untuk pengecekan keabsahan data dilakukan peneliti dalam mengecek keaslian data dan kendala dalam peneliatian yang dilakukan dengan tiga cara yaitu ketekunan pengamatan, triangulasi dan perpanjangan waktu. Sebelum mencapai hasil penelitian yang baik dan juga sempurna, perlu adanya tahap-tahap penelitian. Adapun tahap-tahap yang dilakukan peneliti yaitu tahap persiapan, tahap penyusunan proposal, tahap pelaksanaan, dan tahap penyusunan laporan.

\section{HASIL}

\section{Perencanaan Kegiatan Ekstrakurikuler Broadcasting dalam Meningkatkan Kreativitas Peserta Didik di SMKN 4 Malang}

Perencanaan kegiatan ekstrakurikuler broadcasting yang dilakukan SMKN 4 Malang yakni melatar belakangi kegiatan ekstrakurikuler diadakan ialah banyaknya minat dari peserta didik yang mengikuti kegiatan ekstrakurikuler broadcasting dan didorong oleh peserta didik yang berantusias ingin belajar tentang perfilman untuk meningkatkan kreativitasnya melalui bidang IT. Tujuan diadakannya kegiatan ini adalah untuk membuat peserta didik yang tidak dari jurusan Multimedia (MM) juga bisa belajar tentang IT di ekstrakurikuler broadcasting.

Perencanaan juga memiliki tujuan untuk melangsungkan suatu organisasi bisa berjalan dengan baik. Dengan adanya perencanaan juga awal sebuah kegiatan yang akan dijalankan. Dengan adanya sebuah tujuan perencanaan bisa maksimal dalam penyelenggaraan kegiatan ekstrakurikuler broadcasting.

Perencanaan sendiri juga memiliki manfaat untuk peserta didik bisa berkembang melalui kegiatan ekstrakurikuler broadcasting sendiri. Manfaat kegiatan ekstrakurikuler ini sangatlah banyak terutama 
yaitu membuat peserta didik kreatif melalui IT dan juga belajar banyak dari pembuatan film mulai dari proses produksi, tahap produksi, dan sampai pasca produksi. Melalui film atau video masyarakat dapat mengerti ekstrakurikuler broadcasting itu seperti apa. Dari situ masyarakat bisa mengetahui juga tentang SMKN 4 Kota Malang. Manfaat lainnya anak-anak yang di luar kelas Multimedia dan Animasi juga bisa belajar seperti peserta didik Multimedia. Untuk peserta didik dari jurusan Multimedia bisa mengembangkan lagi bakatnya dan menyebarkan ilmunya kepada teman-temannya yang lain.

Penyusunan alokasi waktu sangatlah penting guna kegiatan tersebut dapat berjalan dengan terstruktur dan baik, untuk melaksanakan kegiatan ekstrakurikuler supaya tidak terjadi bentrok dalam pelaksanaan kegiatan ekstrakurikuler tersebut. Untuk penyusunan program sendiri dilaksanakan pada rapat evaluasi bersama Wakil Kepala Sekolah Bagian Kesiswaan dan juga pembina-pembina ekstrakurikuler yang laiinya, supaya untuk menentukan jadwal bisa berjalan dengan baik dan saling mengerti bisa disetujui sesuai kesepakatan bersama.

Menentukan program yang akan dilaksanakan ada beberapa pihak yang terlibat. Pihak yang terlibat dalam pelaksanaan kegiatan ekstrakurikuler broadcasting terutama pembina kegiatan ekstrakurikuler broadcasting terus dirapatkan dan disepakati oleh wakil kepala kesiswaan dan anggota-anggota broadcast lalu disetujui oleh kepala sekolah. Dengan adanya berbagai pihak yang terlibat bisa diharapkan untuk bisa menjadikan kegiatan ekstrakurikuler broadcating sebagai wadah untuk meningkatkan kreativitas peserta didik.

Program kerja sendiri yang membuat yakni sepenuhnya itu pembina ekstrakurikuler broadcasting, pengurus ekstrakurikuler broadcasting, dan juga anggota broadcasting. Pihak sekolah hanya mengawasi dan mengevaluasi program kerja.

Kegiatan ekstrakurikuler broadcasting agar dapat berjalan dengan tertib, maka ekstrakurikuler broadcasting memiliki peraturan-peraturan yang harus dilaksanakan kepada anggota ekstrakurikuler broadcasting. Dalam tata tertib kegiatan ekstrakurikuler broadcasting ini yang menentukan yaitu pembina dan kesepakatan bersama peserta didik yang mengikuti kegiatan ekstrakurikuler broadcasting tersebut. Dengan diadakannya peraturan untuk anggota ekstrakurikuler broadcasting dapat mentaati peraturan tersebut dan melaksanakan kegiatan ekstrakurikuler broadcasting dengan baik.

\section{Pengorganisasian Kegiatan Ekstrakurikuler Broadcasting dalam Meningkatkan Kreativitas Peserta Didik}

Pengorganisasian merupakan suatu langkah yang dilakukan setelah perencanaan. Pengorganisasian ialah penentuan tugas dan tanggung jawab yang harus dilaksanakan oleh setiap orang yang menerima jabatan tertentu demi terlaksananya kegiatan ekstrakurikuler broadcasting dengan baik. Untuk mengikuti kegiatan ekstrakurikuler broadcasting juga memiliki ketetapan ataupun syarat menjadi anggota di kegiatan ekstrakurikuler broadcasting itu tidak ada tes seperti halnya masuk sekolah semua peserta didik bisa ikut ekstrakurikuler broadcasting. Kegiatan ekstrakurikuler broadcasting ini dilakukan di luar jam sekolah, yang mengikuti kegiatan ekstrakurikuler broadcasting ini yaitu peserta didik SMKN 4 Malang. Karena ekstrakurikuler broadcasting ini merupakan tempat belajar dan mengembangkan bakat dan minat peserta didik.

Ekstrakurikuler broadcasting juga melaksanakan kegiatan regenerasi yang merupakan hal sangat penting dalam roda organisasi. Dengan regenerasi bisa membentuk organisasi lebih baik dari sebelumnya. Untuk melaksanakan regenerasi juga mempunyai waktu yang tepat, yaitu pada setiap tahun ajaran baru, dan sasaran regenerasi adalah kelas sepuluh karena kelas sepuluh wajib mengikuti kegiatan Ekstrakurikuler Pilihan dan Ekstrakurikuler Wajib.

Menjadikan organisasi yang baik maka untuk menjadi pengurus juga melakukan pemilihan keanggotaan serta bagian-bagian yang diinginkan. Dalam kegiatan ekstrakurikuler broadcasting ini bisa diikuti siapa saja ikut kegiatan ekstrakurikuler broadcasting untuk peserta didik, tetapi untuk pengurus sendiri di utamakan kelas sepuluh karena pada kelas sebelas peserta didik melaksanakan praktek kerja industri (prakerin), dan kelas dua belas fokus pada Ujian Nasional. Untuk pembagian menjadi kadidat ketua itu rekomendasi dari pembina, dan untuk mengisi sie-sie peminatan peserta didik sendiri. Dan 
juga menjadi pengurus juga mengisi form yang diberikan pembina melalui online dan peserta didik juga menjawab berbagai pertanyaan dan dibuat video dikirim kepada pembina.

Syarat menjadi anggota juga melakukan kegiatan diklat. Diklat sendiri merupakan awal pembentukan karakter mental dan pelatihan terhadap peserta didik dalam kegiatan ekstrakurikuler broadcasting. Dengan hal tersebut peserta didk juga bisa membaur dan kenal satu sama lain dan juga bisa bekerja dengan tim, karena di kegiatan broadcasting ini lebih banyak bekerja dengan tim.

Menjadikan organisasi yang baik juga didampingi guru atau pembina yang baik. Hal ini diterapkan pada kegiatan ekstrakurikuler broadcasting yaitu menetapkan seorang alumni yang mempunyai pengalaman dalam kegiatan ekstrakurikuler broadcasting. Yang paling penting juga pembina kegiatan ekstrakurikuler broadcasting peserta didiknya bisa mendapatkan prestasi-prestasi untuk sekolah.

Menjadi pembina dalam kegiatan ekstrakurikuler broadcasting di SMKN 4 Malang tidak mudah pada dasarnya pembina dituntut bisa mempertahankan anggota yang ikut dalam kegiatan ekstrakurikuler broadcasting. Dan tidak hanya itu pembina juga menuntut peserta didik lebih kreatif dalam kegiatan ekstrakurikuler broadcasting dan juga bisa memiliki prestasi-prestasi untuk SMKN 4 Malang.

Menetapkan penanggung jawab dalam kegiatan ekstrakurikuler broadcasting ini adalah Kepala Sekolah sebagai penanggung jawab maupun penasehat, Wakil Kepala Sekolah Bagian Kesiswaan, pembina kegiatan ekstrakurikuler broadcasting dan juga pengurus serta anggota broadcasting.

\section{Pelaksanaan Kegiatan Ekstrakurikuler Broadcasting dalam Meningkatkan Kreativitas Peserta Didik}

Pelaksanaan merupakan langkah ketiga setelah kegiatan perencanaan dan pengorganisasian. Pelaksanaan merupakan suatu implementasi dari perencanaan dan pengorganisasian. Pada pelaksanaan ini yang pertama dilakukan yaitu waktu pelaksanaan kegiatan ekstrakurikuler broadcasting di SMKN 4 Kota Malang. Kegiatan ekstrakurikuler ini mempunyai alokasi waktu yang sudah direncanakan sebelumnya dalam pelaksanaan supaya tidak menganggu jam pelajaran. Dengan hal bisa diharapkan partisipasi peserta didik juga banyak peminat terhadap kegiatan ekstrakurikuler terutama kegiatan ekstrakurikuler broadcasting ini. Kegiatan ekstrakurikuler broadcasting ini dilaksanakan pada hari Sabtu dan Kamis, pada hari Kamis dilaksanakan sepulang sekolah yaitu jam empat sore, dan pada hari sabtu dilaksanakan pada pukul sembilan pagi hingga selesai.

Kegiatan yang dilaksanakan dalam kegiatan ekstrakurikuler broadcasting yaitu membuat konten film pendek maupun video. Ekstrakurikuler broadcasting ini banyak melakukan praktik terutama praktek dalam pembuatan film pendek maupun video-video dan dokumentasi pada acara sekolah. Akan tetapi kegiatan ekstrakurikuler dalam pelaksanaan pembuatan konten film pendek maupun video tidak selalu berjalan dengan ada halangan tertentu seperti halangan pada cuaca karena dalam kegiatan ekstrakurikuler broadcasting ini banyak dilakukan di lapangan.

Pembuatan konten film pendek maupun video yang pertama yaitu pembentukan crew dalam pelaksanaannya. Untuk pembagian crew sendiri dilakukan pada peserta didiknya yang memilih sesuai peminatannya peserta didik itu sendiri dimana. Pembagian crew sendiri juga didampingi oleh pembina kegiatan ekstrakurikuler broadcasting. Apabila ada peserta didik yang belum bisa mengoperasikan dalam pembuatan film pendek maupun video, juga diajari karena tujuan dari ekstrakurikuler sendiri belajar.

Keberhasilan dari kegiatan ekstrakurikuler broadcasting ini juga didasari dari tentor dalam pelaksanaan kegiatan yang telah dilaksanakan maupun sebelum direncanakan. Untuk yang menjadi tentor pada kegiatan ekstrakurikuler broadcasting yaitu peran dari alumni seperti pembina ekstrakurikuler broadcasting sendiri dan apabila pembina ada kekurangannya biasanya minta bantuan alumni-alumni yang lainnya juga membantu mengisi materi dalam kegiatan ekstrakurikuler broadcasting.

Peran alumni dalam suatu organisasi sangatlah membantu untuk pelaksanaan kegiatan ekstrakurikuler broadcasting. Di SMKN 4 Malang sendiri peran alumni sangatlah berpengaruh dalam kegiatan ekstrakurikuler broadcasting sendiri, seperti pembina ekstrakurikuler broadcasting diambil dari alumni SMKN 4 Kota Malang sendiri. Dan ada beberapa alumni juga ikut membantu dalam 
pelaksanaan kegiatan diklat, hari ulang tahun ekstrakurikuler broadcasting dan juga mengisi materi pada saat kegiatan ekstrakurikuler broadcasting berlangsung. SMKN 4 Kota Malang juga mempunyai public figur di Indonesia seperti Bayu SKAK, peran Bayu SKAK sangatlah berpengaruh di dalam kegiatan ekstrakurikuler broadcasting yaitu mendukung property yang kurang, baik dalam pembuatan film maupun video.

\section{Evaluasi Kegiatan Ekstrakurikuler Broadcasting dalam Meningkatkan Kreativitas Peserta Didik}

Evaluasi dalam setiap organisasi sangatlah penting dan berpengaruh dalam kedepannya lebih baik lagi. Evaluasi yang baik dilakukan dengan jangka waktu panjang maupun pendek untuk menilai kinerja setiap individu maupun program keseluruhan dalam orgnanisasi yang dikerjakan. Di lakukannya evaluasi bertujuan untuk membuat organisasi lebih baik lagi. Untuk aspek yang dievaluasi yakni hambatan. Setiap organisasi dalam pelaksanaan kegiatan selalu ada setiap kendala atau hambatan. Terutama kegiatan ekstrakurikuler broadcasting ini mendapatkan beberapa hambatan dalam pelaksanaan kegiatannya. Hambatan dalam kegiatan ekstrakurikuler broadcasting yaitu masalah pendanaan, kurangnya alat dalam proses pembuatan film pendek maupun video, dan juga kurangnya fasilitas seperti base camp untuk menyimpan alat-alat untuk praktek pembuatan film pendek maupun video.

Bila ada kendala dalam kegiatan ekstrakurikuler broadcasting, maka ada cara mengatasi kendala dari kegiatan ekstrakurikuler broadcasting sangat diperlukan karena dengan adanya cara mengatasi kegiatan ini dapat terlaksana dengan baik dan juga sesuai yang diharapkan. Dengan adanya evaluasi juga bisa memecahkan setiap hambatan yang ada seperti dengan kurangnya dana pada kegiatan ekstrakurikuler broadcasting peserta didik jualan makanan ringan di sekolah dan juga pada waktu Car Free Day (CFD) setiap hari Minggu. Kemudian untuk peralatan yang kurang biasanya peserta didik memiliki sendiri dan biasanya menyewa. Dan juga apabila untuk tidak ada tempat base camp atau sekretariat khusus ekstrakurikuler broadcasting peserta didik biasanya kumpul di tempat kontrakan pembina. Dengan cara-cara tersebut kegiatan ekstrakurikuler bisa berjalan dengan baik dan sesuai yang diharapkan mendapatkan prestasi yang baik.

Peran dalam evaluasi dalam organisasi sangatlah berpengaruh untuk organisasi lebih baik. Untuk peran dalam pelaksanaaan evaluasi juga bisa mengharapkan memberikan masukan yang baik untuk kemajuan suatu organisasi tersebut. Dengan hal tersebut yang menjadi peran dalan kegiatan ekstrakurikuler broadcasting yaitu Kepala Sekolah, Wakil Kepala Bagian Kesiswaan, Pembina dan juga Ketua ekstrakurikuler. Untuk program kerja yang mengevaluasi yaitu pembina dan juga angota-anggota broadcasting.

Penentuan alokasi waktu yang diadakan itu sangat penting untuk menanggulangi jadwal yang bentrok. Dengan adanya waktu yang telah ditetapkan bisa memberikan pelaksanaan evaluasi dengan baik. Waktu evaluasi yang dilaksanakan yaitu pada setiap tahun yaitu tepatnya pada akhir tahun ajaran kenaikan kelas. Dan juga pada setiap bulan juga dilaksanakan evaluasi anggota melalui presensi siapa saja yang banyak tidak hadir dan jarang ikut kegiatan ekstrakurikuler broadcasting.

\section{Kreativitas yang Didapat Oleh Peserta Didik dalam Mengikuti Kegiatan Ekstrakurikuler Broadcasting}

Setiap manusia memiliki kelebihan dan kekurangan masing tapi manusia pasti mempunyai ide-ide kreatif yang dihasilkan dari kekurangan maupun kelebihannya. Kegiatan ekstrakurikuler broadcasting sebagai wadah peserta didik yang hobi atau belajar dalam dunia broadcasting ini, memiliki jenis kreativitas yang dihasilkan. Jenis kreativitas yang dihasilkan dalam pelaksanaan kegiatan ekstrakurikuler broadcasting sangat berbeda-beda setiap individu pada peserta didik, seperti halnya kreativitas pada produksi maupun pasca produksi. Jenis kreativitas yaitu mencari gambar atau angel yang dibuat untuk membuat suatu konten film pendek video. Tidak hanya itu saja ada kreatif lainnya seperti editing video, editing gambar, dan juga talent untuk pembuatan film pendek.

Ekstrakurikuler broadcasting tidak luput juga memiliki sifat kreatif terhadap peserta didik yang mengikuti. Sifat peserta didik ini sangat berpengaruh juga untuk mencapai hasil atau prestasi yang baik. 
Sifat kreatif yang didapat peserta didik dalam mengikuti kegiatan ekstrakurikuler broadcasting yaitu memikirkan untuk membuat konten video atau film pendek yang membutuhkan transkrip narasi dan berpikir secara out of the box. Seperti short movie dengan judul Maaf yang berisi tentang seorang anak yatim piatu yang sekolah dengan biaya dari kakaknya yang bekerja sebagai badut untuk bisa menghidupi dirinya dan adiknya.

Produk perolehan dari mengikuti kegiatan ekstrakurikuler broadcasting ini sangat penting. Untuk produk yang dihasilkan akan bisa memberikan manfaat bagi sekolah maupun peserta didik. Produk yang dihasilkan dalam mengikuti kegiatan ekstrakurikuler broadcasting yaitu produk-produk seperti video atau film pendek, dan juga produk berupa prestasi-prestasi dalam mengikuti lomba-lomba.

\section{PEMBAHASAN}

\section{Perencanaan Kegiatan Ekstrakurikuler Broadcasting dalam Meningkatkan Kreativitas Peserta Didik di SMKN 4 Malang}

Perencanaan merupakan kegiatan awal yang dilakukan sebelum masuk dalam proses pelaksanaan suatu program kegiatan. Berdasarkan hasil penelitian di SMKN 4 Kota Malang ini mengambil penelitian kegiatan ekstrakurikuler broadcasting. Hal ini sesuai dengan Peraturan Menteri Pendidikan dan Kebudayaan Republik Indonesia Nomor 81A Tahun 2013 tentang Implementasi Kurikulum menjelaskan bahwa jenis kegiatan ekstrakurikuler memiliki salah satu bentuk latihan/olah bakat/prestasi meliputi pengembangan bakat melalui olahraga, kesenian, budaya, cinta alam, jurnalistik, broadcasting, teater, keagamaan, dan lainnya. Berdasarkan hasil temuan peneliti di SMKN 4 Kota Malang, bahwa langkah awal yang dilaksanakan yaitu menetapkan tujuan kegiatan. Hal ini dengan pendapat Purwanto (2008) bahwa dalam melakukan perencanaan terdapat beberapa langkah yang harus dilakukan yaitu menentukan dan merumuskan tujuan yang hendak akan dicapai, meneliti masalah-masalah yang akan dilakukan, mengumpulkan data dan informasi yang diperlukan, serta merumuskan bagaimana masalah-masalah itu akan dipecahkan. Peneliti dalam perencanaan kegiatan ekstrakurikuler broadcasting didapati juga tentang tata tertib yang dilaksanakan dalam kegiatan ekstrakurikuler broadcasting. Hal ini juga didukung dengan pendapat Zulkarnain (2018) yang menjelaskan sekolah menetapkan tujuan, jenis kegiatan, dan sasaran kegiatan. Dalam perencanaan, akan ditetapkan rencana strategi pelaksanaan kegiatan ekstrakurikuler. Dalam menetapkan strategi pelaksanaan, harus ditetapkan pula penanggungjawab dari keseluruhan program kegiatan ekstrakurikuler (Zulkarnain, 2018).

\section{Pengorganisasian Kegiatan Ekstrakurikuler Broadcasting dalam Meningkatkan Kreativitas Peserta Didik di SMKN 4 Malang}

Pengorganisasian sangatlah penting dilakukan untuk bisa berjalannya suatu kegiatan dengan baik. Hasil temuan yang didapatkan oleh peneliti di SMKN 4 Kota Malang, proses pengorganisasian meliputi: (a) pelaksanaan pengorganisasian; (b) tugas dan tanggung jawab. Pelaksanaan pengorganisasian di SMKN 4 Kota Malang meliputi, ketetapan menjadi anggota kegiatan ekstrakurikuler broadcasting, regenerasi pengurus organisasi, persyaratan menjadi pengurus, dan penetapan diklat. Dan juga tugas dan tanggung jawab ekstrakurikuler broadcasting meliputi, kriteria menjadi pembina, tugas pembina, penanggung jawab kegiatan ekstrakurikuler broadcasting. Hal tersebut sesuai dengan teori Purwanto (2008) bahwa adanya pembagian tugas atau pekerjaan yang sesuai dengan kemampuan, keahlian, dan bakat masing-masing, sehingga dapat menimbulkan hubungan yang harmonis dan kooperatif.

Ketetapan menjadi pembina di kegiatan ekstrakurikuler broadcasting di SMKN 4 Malang sendiri ialah mempunyai pengalaman yang diutamakan, dan terutama harus memiliki prestasi yang bisa mengembangkan peserta didik mempunyai prestasi di luar sekolah ataupun di lingkup sekolah sendiri. Jadi peserta didik bisa mengikuti kegiatan ekstrakurikuler broadcasting tidak hanya sekedar tahu tentang broadcasting tetapi juga bisa memiliki prestasi melalui kegiatan ekstrakurikuler broadcasting. Hal ini sesuai dengan teori Purwanto (2008) bahwa garis-garis kekuasaan dan tanggung jawab serta hirarki tata kerja jelas tergambar dalam struktur organisasi. 


\section{Pelaksanaan Kegiatan Ekstrakurikuler Broadcasting dalam Meningkatkan Kreativitas Peserta Didik di SMKN 4 Malang}

Pelaksanaan kegiatan merupakan salah sau inti dari sebuah manajemen, karena pelaksanaan merupakan implementasi dari suatu kegiatan yang telah disusun dan direncanakan. Berdasarkan temuan penelitian yang didapatkan oleh peneliti terdapat beberapa tahap pelaksanaan kegiatan ekstakurikuler broadcasting yang meliputi: (a) penyesuaian jadwal pelaksanaan; (b) tentor kegiatan ekstrakurikuler. Sesuai dengan pendapat oleh Kompri (2015) yang menjelaskan untuk penjadwalan waktu dalam kegiatan ekstrakurikuler harus dirancang pada awal tahun atau semester dengan dibimbing oleh kepala sekolah atau wakil kepala sekolah bagian kurikulum dan peserta didik. Supaya berjalannya ekstrakurikuler dengan lancar dan mencapai apa yang diharapkan oleh sekolah maka harus mempunyai tentor dalam pelaksanaan kegiatan ekstrakurikuler broadcasting di SMKN 4 Kota Malang. Hal tersebut sesuai dengan pendapat Soiatin (dalam Zulkarnain, 2018) bahwa tujuan-tujuan yang telah ditetapkan dan kontribusi terdapat terwujudnya visi dan misi sekolah yaitu bahwa pelaksanaan kegiatan ekstrakurikuler dibina oleh petugas khusus sesuai dengan bidang dan keahlian dan bertanggungjawab kepada Kepala Sekolah.

\section{Evaluasi Kegiatan Ekstrakurikuler Broadcasting dalam Meningkatkan Kreativitas Peserta Didik di SMKN 4 Malang}

Kegiatan ekstrakurikuler broadcasting memiliki beberapa tahap untuk melaksanakan evaluasi, yaitu: (a) aspek yang dievaluasi; (b) berperan dalam evaluasi. Sesuai dengan pendapat yang diungkapkan Zulkarnain (2015) bahwa pengevaluasian program ini dimaksudkan untuk mengumpulkan data atau informasi mengenai tingkat keberhasilan yang dicapai peserta didik. Penilaian dapat dilakukan sewaktu-waktu untuk menetapkan tingkat keberhasilan peserta didik pada tahap-tahap tertentu dan untuk jangka waktu tertentu berkenaan dengan proses dan hasil kegiatan ekstrakurikuler. Hal ini sesuai dengan kegiatan ekstrakurikuler broadcasting yang ada di SMKN 4 Kota Malang, karena pada evaluasi dilakukan yaitu pengumpulan data informasi mengenai tingkat keberhasilan lalu evaluasi dilaksanakan. Ada beberapa pihak yang berperan dalam evaluasi broadcasting untuk menilai suatu kegiatan ekstrakurikuler broadcasting yang dilaksanakan. Hal ini sesuai dengan ungkapan Zulkarnain (2018) pengawasan kegiatan ekstrakurikuler dilakukan secara internal oleh sekolah dan eksternal oleh pihak yang terlibat kinerja kordinator diawasi oleh Waka Kesiswaan, kinerja pelatih diawasi oleh kordinator, dan perkembangan siswa diawasi oleh pelatih.

\section{Kreativitas yang Didapat Oleh Peserta Didik dalam Mengikuti Kegiatan Ekstrakurikuler Broadcasting dalam Meningkatkan Kreativitas Peserta Didik di SMKN 4 Malang}

Setiap orang memiliki kreativitas yang berbeda-beda setiap individu ntuk cara berpikir maupun berperilaku. Kegiatan ekstrakurikuler broadcasting sebagai wadah untuk mengembangkan dan belajar megenai broadcasting. Hal ini sesuai dengan Hartono (2014) mengemukakan bahwa peserta didik pada dasarnya merupakan manusia yang sedang dalam masa pertumbuhan dan perkembangan, yang memerlukan bantuan orang lain, untuk menjalani pertumbuhan dan perkembangannya. Di SMKN 4 Malang sendiri kreativitas dalam mengikuti kegiatan ekstrakurikuler broadcasting mempunyai produk yang dihasilkan yakni produk. Kreativitas dalam dimensi product adalah merupakan upaya kreativitas yang berfokus pada produk atau apa yang dihasilkan oleh individu baik sesuatu yang baru atau original atau sebuah penggabungan yang inovatif dan kreativitas yang berfokus pada produk kreatif menekankan original.

\section{SIMPULAN}

Kesimpulan dari penelitian ini yaitu: (1) perencanaan kegiatan ekstrakurikuler broadcasting meliputi latar belakang suatu kegiatan ekstrakurikuler broadcasting, tujuan ekstrakurikuler broadcasting meliputi penerapan tujuan ekstrakurikuler broadcasting, penerapan manfaat, dan juga menentukan jadwal, penyusunan program meliputi menentukan pihak yang terlibat dalam perencanaan kegiatan ekstrakurikuler broadcasting dan juga tata tertib kegiatan ekstrakurikuler broadcasting; 
(2) pengorganisasian di SMKN 4 Malang meliputi pelaksanaan pengorganisasian yaitu ketetapan menjadi seorang anggota ekstrakurikuler broadcasting, regenerasi pengurus organisasi ekstrakurikuler broadcasting, persyaratan menjadi pengurus, dan penetapan untuk dilaksanakannya diklat. Dalam pengorganisasian kegiatan ekstrakurikuler broadcasting juga memiliki tugas dan tanggung jawab yang harus dilaksanakan yaitu; kriteria menjadi pembina, tugas pembina, dan juga penanggung jawab dalam kegiatan ekstrakkurikuler broadcasting; (3) pelaksanaan kegiatan ekstrakurikuler broadcasting di SMKN 4 Kota Malang meliputi waktu pelaksanaan yang terdiri dari yang ikut berperan dalam pembuatan program kerja, pelaksanaan pembuatan program kerja, dan juga pelaksanaan kegiatan ekstrakurikuler broadcasting. pelaksanaan yang dilaksanakan yaitu, membuat film pendek atau video, dan juga pembentukan crew. Memiliki tentor dalam pelaksanaan, tentor tersebut meliputi tentor dalam kegiatan ekstrakurikuler broadcasting dan juga peran alumni ikut serta; (4) evaluasi kegiatan ekstrakurikuler broadcasting dalam meningkatkan kreativitas peserta didik yaitu meliputi yaitu hambatan kegiatan ekstrakurikuler broadcasting dan juga cara mengatasinya; (5) Kreativitas yang didapat oleh peserta didik dalam mengikuti egiatan ekstrakurikuler broadcasting yaitu meliputi kreativitas yag di dapat oleh perserta didik dalam kegiatan ekstrakurikuler broadcasting meliputi, jenis kreatif, sifat kreatif, dan juga produk yang dihasilkan.

\section{DAFTAR RUJUKAN}

Hartono. 2014. Jurnal Pendidikan Jasmani Indonesia, (Online), (https://journal.uny.ac.id/index.php/jpji), diakses tanggal 10 juni 2019.

Indarti, A. 2017. Manajemen Kegiatan Ekstrakurikuler Broadcasting di SMKN 1 Magelang. (Online), (http:// webcache.googleusercontent.com/search?q=cache:SfIABh09m40J:journal.student.uny.ac.id/ojs/index.php/ fipmp/article/download/7692/7320+\&cd=1\&hl=id\&ct=clnk\&gl=id), diakses 1 Juni 2019.

Peraturan Menteri Pendidikan dan Kebudayaan Nomor 62 Tahun 2013 tentang Implementasi Kurikulum. Guru Karto (online), (https://www.gurukatro.com/2015/12/permendikbud-no-62-tahun-2014-tentang.html), diakses 16 Februari 2018.

Peraturan Menteri Pendidikan dan Kebudayaan. 2014. Permendikbud Nomor 62 Tahun 2013 Tentang Implementasi Kurikulum. (Online), (https://www.gurukatro.com/2015/12/permendikbud-no-62-tahun-2014-tentang.html), diakses 16 Februari 2018.

Peraturan Menteri Pendidikan dan Kebudayaan Nomor 81A Tahun 2013 tentang Implementasi Kurikulum. Scribd (online), (https://www.scribd.com/mobile/doc/164747967/SALINAN- Permendikbud-Nomor-81A-Tahun2013-Tentang-Implementasi -Kurikulum-Garuda), diakses 16 Februari 2019.

Purwanto, N. 2008. Dasar-dasar Ilmu Pendidikan. Yogyakarta: Ar-ruzz media.

Ulfatin, N. 2015. Metode Penelitian Kualitatif di Bidang Pendidikan: Teori dan Aplikasinya (Studi Kasus, Etnografi, Interaksi Simbolik, dan Penelitian Tindakan pada Konteks Manajemen Pendidikan). Malang: Bayumedia Publish.

Zulkarnain, W. 2018. Manajemen Layanan Khusus di Sekolah. Jakarta: Bumi Aksara. 